\title{
Screening of repeated dose toxicity data in safety evaluation reports of cosmetic ingredients issued by the Scientific Committee on Consumer Safety between 2009 and 2019
}

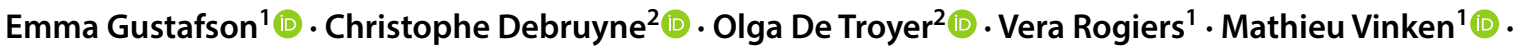 \\ Tamara Vanhaecke ${ }^{1}$ (D)
}

Received: 25 March 2020 / Accepted: 12 August 2020 / Published online: 24 August 2020

(c) The Author(s) 2020

\begin{abstract}
A focal point in the safety evaluation of cosmetic ingredients includes oral repeated dose toxicity testing, which is intended to address the most complex human endpoints. Seven years after the full implementation of the animal testing ban for cosmetic ingredients in the EU, there are still no alternative methods available capable of fully replacing oral repeated dose toxicity testing. Until this issue is resolved, the development of new cosmetic ingredients remains seriously hampered. The present paper describes a thorough screening of the oral repeated dose toxicity data included in safety evaluation reports of cosmetic ingredients addressed in the Annexes of the Cosmetics Regulation (EC) No 1223/2009, issued by the Scientific Committee on Consumer Safety between 2009 and 2019. The liver and the haematological system were identified as the potentially most frequently affected organs upon oral administration of cosmetic ingredients to animals. Evaluation of altered biochemical, morphological, and histopathological parameters related to hepatotoxicity indicated that the most recurrent events are liver weight changes, elevated liver enzymes, and alterations in serum cholesterol and bilirubin levels. Combined listing of affected parameters associated with steatosis and cholestasis indicated the possible occurrence of cholestasis, provoked by a limited number of cosmetic ingredients. The most frequently affected parameters related to the haematological system were indicative of anaemia. An in-depth analysis allowed characterisation of both regenerative and non-regenerative anaemia, pointing to direct and indirect haematotoxicity, respectively. The results presented in this study call for prioritisation of research targeted towards the development of new approach methodologies fit for animal-free repeated dose toxicity evaluation of cosmetic ingredients.
\end{abstract}

Keywords Safety evaluation $\cdot$ Cosmetics $\cdot$ Alternative methods $\cdot$ Repeated dose toxicity

\section{Abbreviations}

ALT

ALP

AST

Alanine aminotransferase

Alkaline phosphatase

Aspartate aminotransferase

Mathieu Vinken and Tamara Vanhaecke share equal seniorship.

Electronic supplementary material The online version of this article (https://doi.org/10.1007/s00204-020-02868-2) contains supplementary material, which is available to authorized users.

Tamara Vanhaecke

Tamara.Vanhaecke@vub.be

1 Department of In Vitro Toxicology and Dermato-Cosmetology, Vrije Universiteit Brussel, Brussels, Belgium

2 WISE Lab, Vrije Universiteit Brussel, Brussels, Belgium
EU ToxRisk Integrated European 'Flagship' Programme Driving Mechanism-based Toxicity Testing and Risk Assessment for the twenty-first century

GGT Gamma-glutamyl transferase

$\mathrm{MCH} \quad$ Mean corpuscular haemoglobin

MCHC Mean corpuscular haemoglobin concentration

MCV Mean cell volume

MoS Margin of safety

NAM(s) New approach methodology(ies)

NGRA Next-generation risk assessment

NOAEL No observed adverse effect level

NOEL No observed effect level

$\operatorname{POD}\left({ }_{\text {sys }}\right) \quad$ Point of departure $\left({ }_{\text {systemic }}\right)$

RBC Red blood cell count

RDT Repeated dose toxicity 


$\begin{array}{ll}\text { SCCS } & \text { Scientific Committee on Consumer Safety } \\ \text { SED } & \text { Systemic exposure dose } \\ \text { SEURAT } & \text { Safety Evaluation Ultimately Replacing } \\ & \text { Animal Testing } \\ \text { TTC } & \text { Threshold of toxicological concern }\end{array}$

\section{Introduction}

The procedure for safety evaluation of cosmetic products and their ingredients has undergone major changes in Europe during the past decade. Since 11 September 2004, the 7th Amendment to Directive 76/768/EEC prohibits animal experiments of finished cosmetic products, while such testing ban on cosmetic ingredients, or combinations thereof, entered into force from 11 March 2009 onwards (EU 1976, 2003). At the same time, a marketing ban (i.e., the marketing in the EU of cosmetic products and their ingredients tested on animals to evaluate their safety) was introduced for all human health effects. The most complex endpoints, namely repeated dose toxicity (RDT), reproductive toxicity, and toxicokinetics, were exempt until 11 March 2013. The ban was taken up in Cosmetics Regulation (EC) No 1223/2009 (EU 2009), despite the fact that non-animal methods capable of assessing those particular toxicological endpoints were lacking.

Today, validated non-animal methods are available for testing short-term and local toxicological endpoints, including skin irritation/corrosion ( ${ }^{1}$ OECD 439, 431, 435, 430) and eye damage/irritation (OECD 491, 492, 437, 438). Additionally, there are validated in vitro/in chemico testing methods for skin sensitisation, some of which have obtained regulatory acceptance as integrated testing approaches (OECD 442D, 442C, 442E, 256). However, 7 years after the full implementation of the animal testing ban for cosmetic ingredients, non-animal methods for testing RDT [i.e., subacute (28 days), sub-chronic ( 90 days), and chronic ( $85 \%$ of expected lifetime) studies], are still lacking.

According to Cosmetics Regulation (EC) No 1223/2009 (EU 2009), the margin of safety (MoS) should be calculated to assess whether a defined exposure to a certain cosmetic ingredient can be considered safe. Despite the fact that the oral route is not the intended, nor expected, route of exposure for the majority of cosmetic products, it is used as a worst-case scenario in the safety assessment unless robust dermal toxicity data are available (SCCS 2018). The MoS is calculated as the ratio of the point of departure ${ }_{\text {sys }}\left(\mathrm{POD}_{\text {sys }}\right)$ over systemic exposure dose (SED). POD sys $_{\text {denotes the }}$ point of departure for systemic toxicity of the substance

\footnotetext{
${ }^{1}$ OECD guidelines are available via https://www.oecd.org/env/ehs/ testing/oecdguidelinesforthetestingofchemicals.htm.
}

under consideration. Typically, the no observed adverse effect level (NOAEL) in the most sensitive organ, historically derived through in vivo RDT testing, is used as POD and consequently is a key point in the overall safety assessment of the cosmetic ingredient. The SED is a function of the concentration present in the cosmetic product, usually topically applied, and its dermal absorption. When the MoS is equal to, or greater than, 100 , the substance is generally considered safe under the intended use conditions (SCCS 2018).

Several EU and industry-funded projects, both completed and ongoing, such as the Safety Evaluation Ultimately Replacing Animal Testing (SEURAT), ${ }^{2}$ the Integrated European 'Flagship' Programme Driving Mechanism-based Toxicity Testing and Risk Assessment for the twenty-first century (EU ToxRisk) ${ }^{3}$ and Cosmetics Europe's "Long Range Science Strategy" programme, are devoted to finding non-animal approaches capable of addressing questions that historically have been answered through RDT testing (Gocht et al. 2015; Daneshian et al. 2016; Desprez et al. 2018; Vinken 2020). It has been proposed that the breakdown of questions addressed by in vivo RDT testing into smaller components would greatly facilitate the development of suitable non-animal methods for their replacement (Laroche et al. 2019). In this context, identification of target organs of RDT (i.e., the organ where the critical effect occurs) as well as the potential toxicological pathways involved are crucial factors. A pragmatic approach to collect such information is by screening safety evaluation reports, or so-called opinions, issued by the Scientific Committee on Consumer Safety (SCCS). Such safety evaluations are performed for Annex substances of Cosmetics Regulation (EC) No 1223/2009, which are cosmetic ingredients where some concern exists with respect to human health (e.g., colourants, preservatives, UV filters, and hair dyes) (EU 2008, 2009). In each opinion, the SCCS addresses direct questions regarding the safety of the specific cosmetic ingredient and performs a safety evaluation of the ingredient with reference to the intended use (SCCS 2018). In the current study, data from the safety evaluations published by the SCCS between 2009 and 2019 were collected with the specific aim to identify potential target organs of RDT and manifestations of the toxicity in those organs.

\footnotetext{
${ }^{2}$ More information regarding the project is available via https:// www.seurat-1.eu/.

${ }^{3}$ More information regarding the project is available via https:// www.eu-toxrisk.eu/.
} 
Table 1 Identification of repeated dose toxicity studies described in 88 safety evaluation reports published between 2009 and 2019

\begin{tabular}{lcl}
\hline Repeated dose toxicity (oral) & $\begin{array}{l}\text { Number of } \\
\text { studies }\end{array}$ & $\begin{array}{l}\text { Number of cos- } \\
\text { metic ingredients }\end{array}$ \\
\hline 28-day toxicity study & 37 & 26 \\
90-day toxicity study & 110 & 79 \\
Teratogenicity study & 120 & 79 \\
Two-generation reproductive & 16 & 13 \\
$\quad$ toxicity study & & \\
Chronic toxicity study & 15 & 9 \\
Carcinogenicity study & 30 & 16 \\
\hline
\end{tabular}

\section{Materials and methods}

The study material consisted of 114 SCCS opinions issued between 22 January 2009 and 31 December 2019 dealing with 101 unique cosmetic ingredients in total. All information used in this study was downloaded from the SCCS website. ${ }^{4}$ Hence, no confidential data were used.

For identification of target organ(s), data were manually collected from oral RDT studies described in the SCCS opinions, thus without access to the raw data submitted to the SCCS. The information was sorted into a Microsoft ${ }^{\circledR}$ Office Excel spreadsheet based on the organ in which the critical effect(s) occurred and from which a NOAEL could be derived. In cases of multiple target organs, the sorting was based on what appeared to be the most relevant and sensitive effect. Further analysis of the data included the listing of all changes in morphological, histopathological, and blood biochemical parameters relevant for the top 2 affected organs and/or organ systems described in 88 opinions containing RDT data.

\section{Results and discussion}

\section{Identification of repeated dose toxicity studies described in the safety evaluation reports}

Among the 101 substances covered in the SCCS opinions included in the study, no adequate oral RDT data for determination of an NOAEL were available for 13 cosmetic ingredients. For 1 of the remaining 89 substances, a readacross approach from other routes of exposure was applied. Hence, 88 opinions contained oral RDT data for which an NOAEL determination and subsequent MoS calculation was feasible (Table 1).

\footnotetext{
${ }^{4}$ SCCS opinions are available for download via https://ec.europa.eu/ health/scientific_committees/consumer_safety_en.
}

A total of 3728 -day oral toxicity studies were available for 26 cosmetic ingredients, indicating that a particular chemical compound may have been subjected to a similar test more than once. For 19 of these 26 ingredients, also 90-day oral toxicity studies were available. However, in many of these cases, the 28-day study was used as a dose range-finding study for the subsequent 90 -day study. In total, there were 11090 -day studies available for 79 cosmetic ingredients. Some of the evaluated cosmetic ingredients have a long history of use and/or have been used in areas other than the cosmetics field, which might contribute to cases where multiple studies have been conducted for the same ingredient. In opinions lacking 90-day oral RDT studies, supporting information was provided from open literature (2) and through read-across from 28-day studies (5) or from chronic studies (2). A total of 120 teratogenicity studies were provided for 79 cosmetic ingredients, again suggesting that a specific ingredient may have been repeatedly subjected to similar tests. Because teratogenicity studies are specifically designed to assess the effects on maternal health, foetal abnormalities and/or altered growth of the foetus, they were not further considered in the present study. Chronic, carcinogenicity, and two-generation reproductive toxicity studies were represented to a lesser extent in the SCCS opinions, albeit displaying a similar pattern of studies repeated for a certain ingredient.

\section{Description of target organs in oral repeated dose toxicity studies included in the safety evaluation reports}

As the 90-day oral RDT studies are specifically designed to provide information on toxic effects and indicate target organs upon repeated exposure (OECD 2018), information on target organs and critical effects have primarily been retrieved from those studies. Exceptions include the nine opinions previously mentioned where the data described in the opinions were provided from open literature and through read-across from other oral studies. Of the 88 opinions containing oral RDT data (listed in Online Resource 1), eight cosmetic ingredients were devoid of adverse effects at the maximum allowed test dose ( $1000 \mathrm{mg} / \mathrm{kg}$ bodyweight) resulting in the determination of an NOAEL and a no observed effect level (NOEL) at this dose for 6 and 2 ingredients, respectively, while an NOAEL was set at the highest tested dose $(<1000 \mathrm{mg} / \mathrm{kg}$ bodyweight $)$ for five cosmetic ingredients. Consequently, based on the lack of observed adverse effects, it was not possible to identify the target organ for these 13 compounds.

Critical effects and/or target organs used to set an NOAEL were identified through RDT studies in 75 opinions. Among these 75 opinions, the liver was identified as the target organ for 20 cosmetic ingredients, based on alterations in blood 


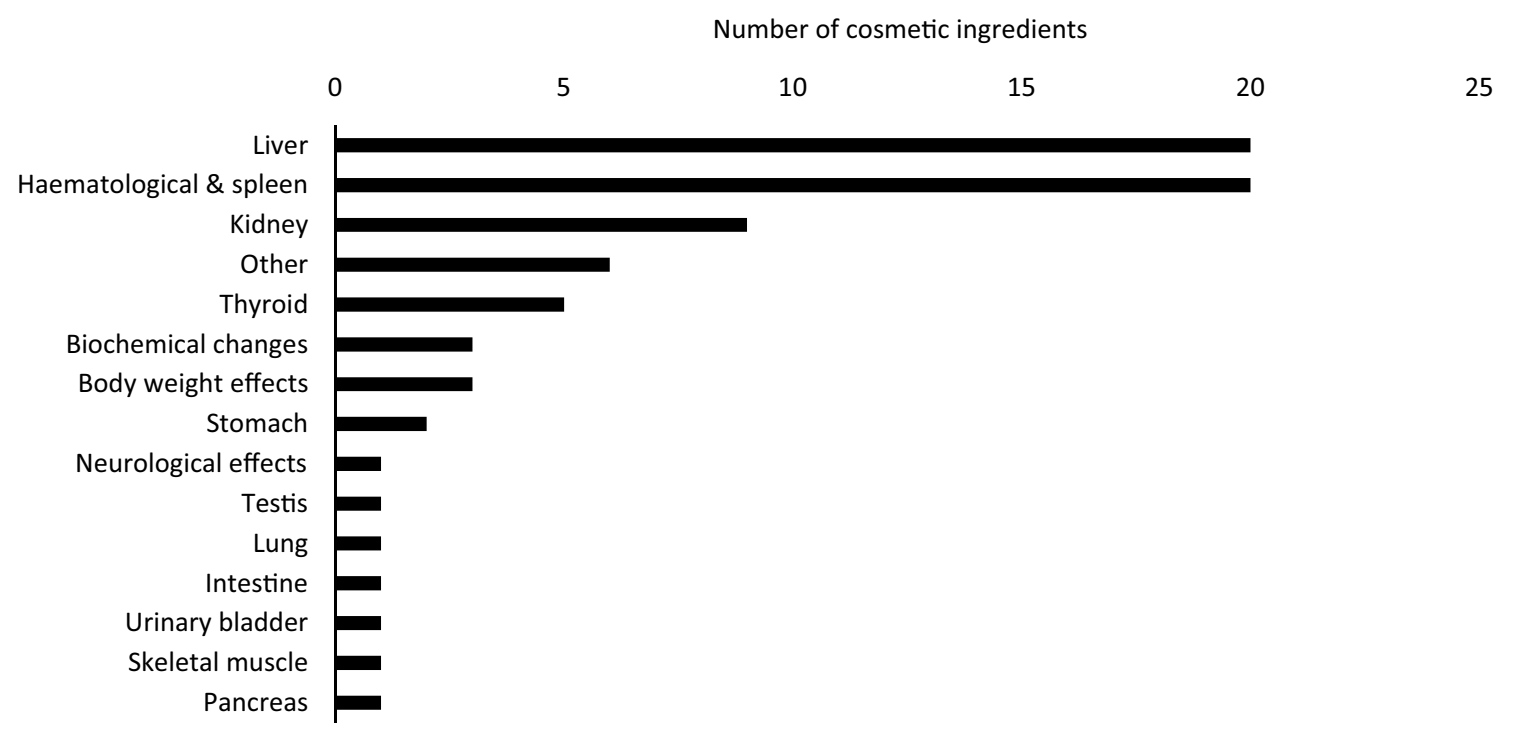

Fig. 1 Identification of target organs and critical effects of 75 cosmetic ingredients from oral repeated dose toxicity studies described in the safety evaluation reports issued between 2009 and 2019

biochemistry, including enzyme activities, and on histopathological changes (e.g., vacuolisation and necrosis), making it one of the most frequent targets of toxicity. Due to its anatomical proximity to the digestive tract and high blood flow rate, together with its key role in the biotransformation of xenobiotics, it is not surprising that the liver appears as a main target of toxicity upon repeated oral exposure (Hayes and Kruger 2014).

Based on aberrant haematological parameters such as number of blood cells, amount of haemoglobin, and morphological and/or histopathological changes in the spleen, the haematological system and/or the spleen, often in combination and, therefore, paired as one organ system, were found to be commonly affected. The haematological system is complex, multicellular and in a dynamic state of cell proliferation, differentiation, activation, and maturation. The spleen is responsible for red blood cell production and removal of damaged blood cells (Hayes and Kruger 2014; Mebius and Kraal 2005). Hence, it is conceivable to assume that the turnover and alteration of cells in the blood, as well as the high blood flow through the spleen, makes the system vulnerable to chemical-induced systemic toxicity.

The third most affected organs, although with markedly lower occurrence compared to the liver and the haematological system, were demonstrated to be the kidneys. In most cases, this was based on histopathological changes (Fig. 1) such as cellular degeneration (3) and the presence of hyaline droplets (3) in the renal tubules. However, for the majority of cases, the study descriptions in the SCCS opinions did not allow to determine which part of the tubules were affected. Additionally, hyaline droplets are often seen as a non-specific response and thus of limited relevance to humans, especially when exclusively observed in male rats, which was the case for two out of the three compounds. The kidneys are responsible for maintaining a consistent internal environment by regulating the body's salt, water, and acid-base balance. This is achieved through blood filtration, approximately $25 \%$ of the cardiac output, and excretion of waste products (Barnett and Cummings 2019). Moreover, the epithelial cells lining the proximal tubules contain a plethora of transport proteins, often leading to accumulation of chemical compounds, resulting in a high concentration of chemicals within the tubular epithelial cells relative to that in plasma (Barnett and Cummings 2019; Hayes and Kruger 2014) which may partly explain the cellular degeneration observed in the renal tubules. Collectively, these properties make the kidneys sensitive to toxicants and, thus, not an unexpected target for systemic toxicity.

\section{Identification of morphological, histopathological, and biochemical changes related to hepatotoxicity in oral repeated dose toxicity studies described in the safety evaluation reports}

Following the identification of the liver as the main target for toxicity in oral RDT studies, the relevance of this finding was further investigated by listing potentially toxicological parameters related to hepatotoxicity as described in the SCCS opinions (Fig. $2 \mathrm{a}$ and b). In addition to the 20 cosmetic ingredients demonstrated to elicit a critical effect in the liver, 29 additional ingredients of the 88 opinions containing oral RDT data also altered one or more parameters related to hepatotoxicity, resulting in 49 liver-affecting compounds in total. For 29 of the 88 cosmetic ingredients, a combination of changes in parameters related to hepatotoxicity and haematotoxicity 
A Number of cosmetic ingredients

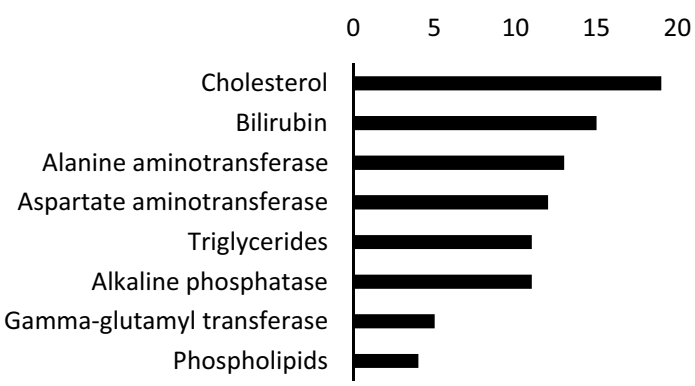

Fig. 2 a Identification of changes in clinical parameters possibly linked to hepatotoxicity in oral repeated dose toxicity studies described for the 49 liver-affecting cosmetic ingredients in safety evaluation reports issued between 2009 and 2019. b Identification of

was seen. Alterations in serum cholesterol and bilirubin levels were the most commonly observed biochemical modifications (Fig. 2a), while altered liver weight represented the most frequently occurring morphological change (Fig. 2b). Deviating levels of one or more liver enzymes were also commonly seen (Fig. 2a), i.e., for 28 substances in total. However, it should be noted that these safety evaluations have not been designed for this specific purpose and the relevance of observed alterations in individual parameters for characterising liver injury must be seen as limited. For example, hepatocellular hypertrophy can reflect adaptive responses to a compound due to, e.g., enzyme induction (Hall et al. 2012). Changes in liver weight can be attributed either to transient adaptive effects or an unfavourable taste of the compound causing a reduced food intake with subsequent reduction in body weight of the test animals, thereby also affecting organ weight (Cattley and Cullen 2013; Vinken et al. 2012). Unaccompanied, many of these deviations are not necessarily regarded as toxicologically relevant and do not always imply adversity. Yet, elevated enzyme activities such as alanine aminotransferase (ALT) and aspartate aminotransferase (AST) reflect hepatocyte damage and may provide a first indication of liver toxicity (David and Hamilton 2010). Consequently, changes in individual parameters have rather limited significance for characterising potential (liver) injury. To accurately identify adversities, a battery of tests that detect clinically important biochemical, histopathological, and morphological parameters needs to be considered.

Certain combinations of effects might, however, be indicative of specific adverse effects. Concomitant increases in serum AST, cholesterol, and triglycerides, alongside fat accumulation in hepatocytes, resulting from impaired balance between the rate of synthesis and the release of triglycerides from the hepatocytes, could imply steatosis-inducing potential of a compound (Hayes and Kruger 2014; Ipsen et al. 2018). Likewise, simultaneous increases in serum alkaline phosphatase (ALP), gamma-glutamyl transferase
B Number of cosmetic ingredients

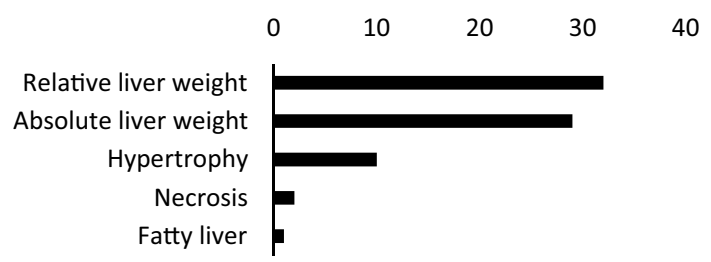

morphological and histopathological changes possibly linked to hepatotoxicity in oral repeated dose toxicity studies described for the 49 liver-affecting cosmetic ingredients in safety evaluation reports issued between 2009 and 2019

(GGT), and bilirubin, in addition to hepatocellular necrosis, are predominant features of cholestatic liver injury, i.e., hepatocellular accumulation of bile (Boone et al. 2005; Greim 2008; Hayes and Kruger 2014; Robles-Diaz et al. 2015). In this context, several compounds covering a wide chemical space and various application areas have been found to induce liver steatotic and cholestatic effects (AlEryani et al 2015; Vilas-Boas et al. 2019). Cosmetic ingredients provoking a change in one or more parameters potentially associated with steatosis and cholestasis are depicted in Tables 2 and 3, respectively. Based on these combined observations, none of the 49 cosmetic ingredients triggered changes in the combination of parameters related to steatosis to a degree prospectively raising concern, i.e., affecting three out of four parameters (Vinken et al. 2012). Two out of the 49 liver-affecting cosmetic ingredients were found to alter three or more of the parameters associated with cholestasis, namely 2,7-naphthalenediol and Basic red 51, and could, therefore, be considered as plausible cholestasis-inducing compounds (SCCS 2010a, 2011).

\section{Identification of morphological, histopathological, and biochemical changes related to the haematological system and the spleen in oral repeated dose toxicity studies described in the safety evaluations}

As holds for the liver, the parameters possibly related to haematotoxicity described in the SCCS opinions were listed. In total, 42 of the 88 cosmetic ingredients induced changes in one or more parameters associated with the haematological system following oral RDT testing. The most frequently observed morphological and histopathological changes in the spleen were alterations in weight and occurrence of haematopoiesis (Fig. 3b). While both effects can be caused by a large variety of insults, the 
Table 2 Identification of cosmetic ingredients provoking a change in at least one parameter associated with steatosis based upon alterations observed in oral repeated dose toxicity studies described for the 49 liver-affecting cosmetic ingredients in safety evaluation reports issued between 2009 and 2019

\begin{tabular}{|c|c|c|c|c|c|}
\hline Cosmetic ingredient & Function & $\uparrow \mathrm{AST}^{*}$ & $\uparrow \mathrm{TG}^{* *}$ & $\uparrow$ Cholesterol & $\begin{array}{l}\text { Hepatic fat } \\
\text { accumulation }\end{array}$ \\
\hline $\begin{array}{l}\text { 5-Amino-6-chloro-o- } \\
\text { cresol }\end{array}$ & $\begin{array}{l}\text { Hair dyeing ingredient used as a precursor for hair } \\
\text { dyeing products. The reaction can be acceler- } \\
\text { ated by the addition of an oxidising agent (e.g., } \\
\text { hydrogen peroxide), but can also be achieved by } \\
\text { air oxidation }\end{array}$ & & & $\mathrm{x}$ & \\
\hline $\begin{array}{l}\text { Acetylated vetiver } \\
\text { oil—AVO }\end{array}$ & Used as a fragrance in perfumes and cosmetics & & & $\mathrm{x}$ & \\
\hline Basic brown 17 & $\begin{array}{l}\text { Hair dyeing ingredient used as a direct dye for hair } \\
\text { colouring products }\end{array}$ & & $\mathrm{x}$ & $\mathrm{x}$ & \\
\hline Basic red 51 & $\begin{array}{l}\text { Hair dyeing ingredient used in direct hair dye for- } \\
\text { mulations and in oxidative hair dyes after mixing } \\
\text { with the oxidative agent }\end{array}$ & & $\mathrm{x}$ & $\mathrm{x}$ & \\
\hline Basic violet 2 & $\begin{array}{l}\text { Hair dyeing ingredient used as a non-reactive hair } \\
\text { colouring agent in non-oxidative hair dye-formu- } \\
\text { lation and oxidative hair dye formulations. Also } \\
\text { used as a colourant (CI } 42,520) \text { in cosmetic prod- } \\
\text { ucts intended to come into contact only briefly } \\
\text { with the skin }\end{array}$ & & & $\mathrm{x}$ & \\
\hline $\begin{array}{l}\text { Bis(butylbenzoate) } \\
\text { diaminotriazine ami- } \\
\text { nopropyltrisiloxane }\end{array}$ & $\begin{array}{l}\text { Used as a UV filter }\left(\lambda_{\max }=310 \mathrm{~nm}\right) \text { proposed to } \\
\text { be used in sunscreen formulations at a maximum } \\
\text { concentration of } 10 \%\end{array}$ & $\mathrm{x}$ & & & \\
\hline $\begin{array}{l}\text { Butylphenyl methylpro- } \\
\text { pional ( } p \text {-BMHCA) }\end{array}$ & $\begin{array}{l}\text {-Used as a fragrance ingredient in many compounds } \\
\text { for cosmetic products as well as in non-cosmetic } \\
\text { products such as household cleaners and deter- } \\
\text { gents }\end{array}$ & & & & $\mathrm{x}$ \\
\hline $\begin{array}{l}\text { Cetylpyridinium } \\
\text { chloride }\end{array}$ & $\begin{array}{l}\text { Used as a disinfectant in mouthwashes cosmetic } \\
\text { products up to a concentration of } 0.1 \% \text {, all other } \\
\text { oral hygiene cosmetic products up to a con- } \\
\text { centration of } 0.5 \% \text {, skin lotions and creams up } \\
\text { to a concentration of } 0.2 \% \text { and anti-perspirant } \\
\text { deodorants up to a concentration of } 2.0 \%\end{array}$ & $\mathrm{x}$ & & & \\
\hline $\begin{array}{l}\text { Decamethylcyclopenta- } \\
\text { siloxane D5 }\end{array}$ & $\begin{array}{l}\text {-Used as volatile excipient in cosmetic products. } \\
\text { It can have many different functions in cos- } \\
\text { metic products including antistatic, emollient, } \\
\text { humectant, solvent, viscosity controlling, and } \\
\text { hair conditioning }\end{array}$ & & & & $\mathrm{x}$ \\
\hline EcoG+ & $\begin{array}{l}\text { Used as a preservative in the internal parts of pack- } \\
\text { aging containers (i.e., the parts of the packaging } \\
\text { in direct contact with the cosmetic product) }\end{array}$ & & & $\mathrm{x}$ & \\
\hline HC blue 15 & $\begin{array}{l}\text { Hair dyeing ingredient used in oxidative hair dyes } \\
\text { as a non-reacting component }\end{array}$ & & $\mathrm{x}$ & $\mathrm{x}$ & \\
\hline HC yellow 13 & $\begin{array}{l}\text { Hair dyeing ingredient used as a hair colouring } \\
\text { agent ("direct dye") in non-oxidative and oxida- } \\
\text { tive hair dye formulations }\end{array}$ & & & $\mathrm{x}$ & \\
\hline $\begin{array}{l}\text { Hydroxyethyl-2-nitro- } \\
p \text {-toluidine }\end{array}$ & $\begin{array}{l}\text { Hair dyeing ingredient used as a direct dye in hair } \\
\text { dye formulations and as a non-reactive dye in } \\
\text { oxidative hair dye formulations }\end{array}$ & $\mathrm{x}$ & & & \\
\hline $\begin{array}{l}\text { Hydroxyethyl- } \\
\text { 3,4-methylenedioxy- } \\
\text { aniline } \mathrm{HCl}\end{array}$ & $\begin{array}{l}\text { Hair dyeing ingredient used in oxidative hair dye } \\
\text { formulations after mixing with the developer } \\
\text { containing hydrogen peroxide }\end{array}$ & & & $\mathrm{x}$ & \\
\hline
\end{tabular}


Table 2 (continued)

\begin{tabular}{|c|c|c|c|c|c|}
\hline Cosmetic ingredient & Function & $\uparrow \mathrm{AST}^{*}$ & $\uparrow \mathrm{TG}^{* *}$ & $\uparrow$ Cholesterol & $\begin{array}{l}\text { Hepatic fat } \\
\text { accumulation }\end{array}$ \\
\hline $\begin{array}{l}\text { Hydroxyethyl- } \\
\text { p-phenylenediamine } \\
\text { sulphate }\end{array}$ & $\begin{array}{l}\text { Hair dyeing ingredient used in oxidative hair dye } \\
\text { formulations }\end{array}$ & & & $\mathrm{x}$ & \\
\hline $\begin{array}{l}\text { Hydroxypropyl } p \text {-phe- } \\
\text { nylenediamine and its } \\
\text { dihydrochloride salt } \\
\text { (A165) }\end{array}$ & $\begin{array}{l}\text { Hair dyeing ingredient used in oxidative hair dye } \\
\text { formulations }\end{array}$ & $\mathrm{x}$ & & $\mathrm{x}$ & \\
\hline $\begin{array}{l}\text { Methylimidazolium- } \\
\text { propyl } p \text {-phenylene- } \\
\text { diamine } \mathrm{HCl} \text { (A166) }\end{array}$ & $\begin{array}{l}\text { Hair dyeing ingredient used in oxidative hair dye } \\
\text { formulations }\end{array}$ & $\mathrm{x}$ & & & \\
\hline $\begin{array}{l}N, N \text { '-bis- } \\
\text { (2-hydroxyethyl)- } \\
\text { 2-nitro-p-phenylene- } \\
\text { diamine }\end{array}$ & $\begin{array}{l}\text { Hair dyeing ingredient used as a direct hair dye for } \\
\text { hair colouring products. Used in oxidative hair } \\
\text { dye formulations with and without mixing with } \\
\text { an oxidising agent (e.g., hydrogen peroxide) }\end{array}$ & & $\mathrm{x}$ & $\mathrm{x}$ & \\
\hline $\begin{array}{l}N \text {-Methyl-2-pyrro- } \\
\text { lidone }\end{array}$ & $\begin{array}{l}\text { Used as a solvent and a surfactant in cosmetic } \\
\text { products }\end{array}$ & & & $\mathrm{x}$ & \\
\hline$o$-Aminophenol & $\begin{array}{l}\text { Hair dyeing ingredient used in oxidative hair dye } \\
\text { formulations }\end{array}$ & $\mathrm{x}$ & & & \\
\hline Phenoxyethanol & $\begin{array}{l}\text { Used as a preservative in cosmetic formulations at } \\
\text { a maximum concentration of } 1.0 \%\end{array}$ & & $\mathrm{x}$ & & \\
\hline $\begin{array}{l}\text { Toluene-2,5-diamine } \\
\text { (sulphate) }\end{array}$ & $\begin{array}{l}\text { Hair dyeing ingredient used in oxidative hair dye } \\
\text { formulations (precursor) }\end{array}$ & $\mathrm{x}$ & & & \\
\hline Vetiveryl acetate & Used as a fragrance in perfumes and cosmetics & & & $\mathrm{x}$ & \\
\hline
\end{tabular}

*Aspartate aminotransferase

**Triglycerides

former is considered as a sensitive indicator of immune toxicity (Kim 2010; Michael et al. 2007). The most commonly affected haematological parameters were changes in red blood cell count (RBC), mean concentration of haemoglobin $(\mathrm{MCH})$ in red blood cells, and haematocrit (i.e., the ratio of the volume of red blood cells to the total blood volume) (Fig. 3a). When decreased, all these parameters are indicative of anaemia, albeit a correct diagnosis requires a more complex assessment (Broadway-Duren and Klaassen 2013; Cascio and DeLoughery 2017) with additional tests generally not included in RDT studies. Commonly analysed parameters related to the haematological system can be used to classify the suspected anaemia as regenerative or non-regenerative (Grimes and Fry 2015). The former encompasses reduced levels of circulating red blood cells and/or other red blood cell parameters such as haemoglobin and haematocrit, which is accompanied by an increase in immature blood cells, i.e., reticulocytes. If the regenerative response is potent enough to counteract the decreased levels of red blood cells, a regenerative anaemia can be diagnosed based on increased erythrocyte mean cell volume (MCV) and subnormal mean corpuscular haemoglobin concentration (MCHC). On the contrary, in non-regenerative anaemia, no increase in the levels of reticulocytes is seen. Non-regenerative anaemia occurs less often as a result of primary haematotoxicity, but is more frequently a complication of various non-haematologic diseases, e.g., inflammation (Grimes and Fry 2015). In Table 4, the cosmetic ingredients that provoked changes in the above-mentioned haematological parameters are listed. Alterations indicative of non-regenerative anaemia (i.e., anaemia with no concomitant increase in reticulocytes) were observed for 2,7-naphthalenediol, erythrosine (CI 45430), disperse violet 1 (1,4-diamino-anthraquinone), HC red 7 , and sodium perborate and perboric acid. This is in line with the finding that 2,7-naphthalenediol, erythrosine (CI 45430), and disperse violet 1 (1,4-diamino-anthraquinone) are believed to target organs other than the haematological system (Online Resource 1). Conversely, HC red 7 , and sodium perborate and perboric acid are believed to target the haematological system and may induce anaemia only as a secondary effect. Again, it is important to keep in mind that these safety evaluation reports of cosmetic ingredients have not been designed to diagnose specific diseases, but rather to describe general toxicity, and thus, the results need to be considered with caution. 
Table 3 Identification of cosmetic ingredients provoking a change in at least one parameter associated with cholestasis based on alterations observed in oral repeated dose toxicity studies described for the 49 liver-affecting cosmetic ingredients in safety evaluation reports issued between 2009 and 2019

\begin{tabular}{|c|c|c|c|c|c|}
\hline Cosmetic ingredient & Function & $\uparrow \mathrm{ALP} *$ & $\uparrow G^{*} T^{*}$ & $\uparrow$ Bilirubin & $\begin{array}{l}\text { Hepato- } \\
\text { cellular } \\
\text { necrosis }\end{array}$ \\
\hline 1,5-Naphthalenediol & $\begin{array}{l}\text { Hair dyeing ingredient used in oxidative and non- } \\
\text { oxidative hair dye formulations }\end{array}$ & & & $\mathrm{x}$ & \\
\hline 2,6-Dihydroxyethylaminotoluene & $\begin{array}{l}\text { Hair dyeing ingredient used as a precursor for hair } \\
\text { colours. It reacts with primary intermediates to } \\
\text { form the final dye-stuff. The reaction can be accel- } \\
\text { erated by the addition of an oxidising agent (e.g., } \\
\text { hydrogen peroxide), but it can also be achieved by } \\
\text { air oxidation }\end{array}$ & & & $\mathrm{x}$ & \\
\hline 2,7-Naphthalenediol & $\begin{array}{l}\text { Used in oxidative and non-oxidative hair dye formu- } \\
\text { lations with a maximum on-head concentration of } \\
1 \%\end{array}$ & & $\mathrm{x}$ & $\mathrm{x}$ & $\mathrm{x}$ \\
\hline 5-Amino-6-chloro- $O$-cresol & $\begin{array}{l}\text { Used as a precursor for hair dyeing products. The } \\
\text { reaction can be accelerated by the addition of an } \\
\text { oxidising agent (e.g., hydrogen peroxide), but can } \\
\text { also be achieved by air oxidation }\end{array}$ & & & $\mathrm{x}$ & \\
\hline Basic brown 17 & $\begin{array}{l}\text { Hair dyeing ingredient used as a direct dye for hair } \\
\text { colouring products }\end{array}$ & & $\mathrm{x}$ & $\mathrm{x}$ & \\
\hline Basic red 51 & $\begin{array}{l}\text { Hair dyeing ingredient used in direct hair dye formu- } \\
\text { lations and oxidative hair dyes after mixing with } \\
\text { the oxidative agent }\end{array}$ & $\mathrm{x}$ & $\mathrm{x}$ & & $\mathrm{x}$ \\
\hline Citric acid (and) silver citrate & $\begin{array}{l}\text { Used as a preservative system in aqueous leave-on } \\
\text { and rinse-off cosmetic products. Citric acid and } \\
\text { silver citrate is used in deodorants }\end{array}$ & $\mathrm{x}$ & & & \\
\hline Diethylene glycol monoethyl ether & $\begin{array}{l}\text { Used in cosmetics and dermatological preparations } \\
\text { and as a solvent in some medicine products. Its } \\
\text { physical properties make DEGEE useful to solubi- } \\
\text { lise lipophilic and hydrophilic compounds. Moreo- } \\
\text { ver, DEGEE enhances the percutaneous absorption } \\
\text { through the skin and mucosal barriers }\end{array}$ & $\mathrm{x}$ & & & \\
\hline EcoG + & $\begin{array}{l}\text { Used as a preservative in the internal parts of pack- } \\
\text { aging containers (i.e., the parts of the packaging in } \\
\text { direct contact with the cosmetic product) }\end{array}$ & $\mathrm{x}$ & & & \\
\hline Hydroxyethyl-2-nitro- $p$-toluidine & $\begin{array}{l}\text { Used as a direct dye in hair dye formulations at a } \\
\text { maximum concentration of } 1 \% \text { and as a non- } \\
\text { reactive dye in oxidative hair dye formulations at a } \\
\text { maximum concentration of } 1 \% \text {, after dilution with } \\
\text { the oxidative agent }\end{array}$ & $\mathrm{x}$ & & $\mathrm{x}$ & \\
\hline Hydroxyethyl-3,4-methylenedioxyaniline $\mathrm{HCl}$ & $\begin{array}{l}\text { Hair dyeing ingredient used in oxidative hair dye } \\
\text { formulations after mixing with the developer con- } \\
\text { taining hydrogen peroxide }\end{array}$ & & & $\mathrm{x}$ & \\
\hline $\begin{array}{l}\text { Hydroxypropyl } p \text {-phenylenediamine and its } \\
\text { dihydrochloride salt (A165) }\end{array}$ & $\begin{array}{l}\text { Hair dyeing ingredient used in oxidative hair dye } \\
\text { formulations }\end{array}$ & & $\mathrm{x}$ & $\mathrm{x}$ & \\
\hline $\begin{array}{l}\text { Methoxypropylamino cyclohexenylidene } \\
\text { ethoxyethylcyanoacetate (S87) }\end{array}$ & $\begin{array}{l}\text { Used as a UV filter in personal care products, includ- } \\
\text { ing sun care cosmetic formulations at a maximum } \\
\text { concentration of } 3 \% \mathrm{w} / \mathrm{w}\end{array}$ & & & $\mathrm{x}$ & \\
\hline$N$-Methyl-2-pyrrolidone & $\begin{array}{l}\text { Used as a solvent and a surfactant in cosmetic } \\
\text { products }\end{array}$ & $\mathrm{x}$ & & & \\
\hline Phenoxyethanol & $\begin{array}{l}\text { Used as a preservative in cosmetic formulations at a } \\
\text { maximum concentration of } 1.0 \%\end{array}$ & $\mathrm{x}$ & & & \\
\hline
\end{tabular}

*Alkaline phosphatase

**Gamma-glutamyl transferase 
A

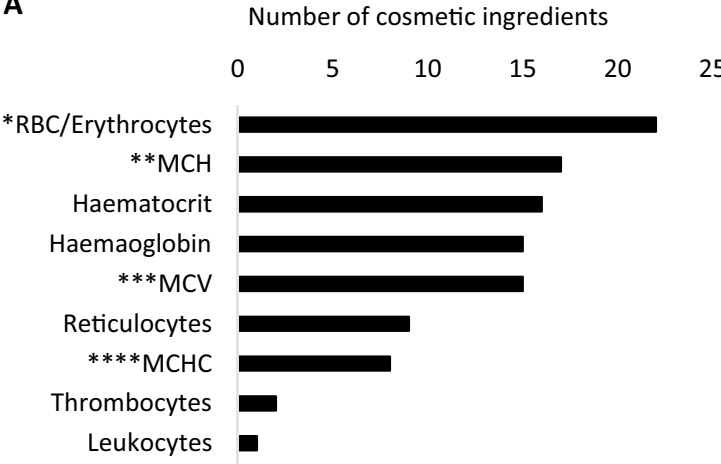

B

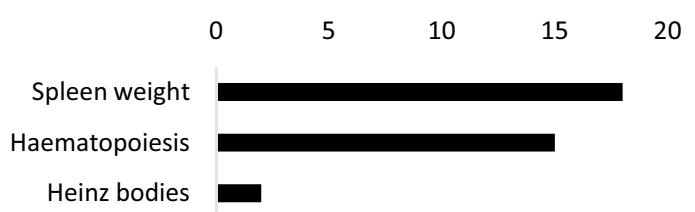

Fig. 3 a Identification of haematological changes possibly linked to toxic effects in the haematological system as described in oral repeated dose toxicity studies for the 42 haematology-affecting cosmetic ingredients in safety evaluation reports issued between 2009 and 2019. b Identification of morphological and histopathological changes possibly linked to toxic effects in the spleen described in

\section{Conclusion}

The goal of the current study was to identify the main target organs and/or critical effects as well as to characterise the manifestations of toxicity of cosmetic ingredients in these organs in oral RDT studies. RDT data were collected from safety evaluation reports published by the SCCS between 2009 and 2019. Not surprisingly, it was found that the most frequently affected organs by cosmetic ingredients were the liver and the haematological system, whose inherent physiological functions make them susceptible to toxicants (Cattley and Cullen 2013; Hayes and Kruger 2014; Mebius and Kraal 2005). It is well known that drug-induced liver injury remains a common cause of the withdrawal of drugs in pre-clinical and even clinical phases of drug development (Lee 2013; Onakpoya et al., 2019). It has also been reported that chemicals from various other application areas could trigger liver adversities such as steatosis and cholestasis (Al-Eryani et al. 2015; Vilas-Boas et al. 2019). Here, for cosmetic ingredients, certain combinations of changes in relevant parameters that could indicate liver steatosis and cholestasis were collected (Tables 2 and 3 ) for all potentially liver-affecting compounds (49). The liver's complexity and diverse functions, in combination with its varied response to injury, require careful consideration of multiple parameters to ensure scientifically valid results. It should be further stressed that the parameters available in the SCCS opinions constitute only a limited part of the clinically relevant information addressed to diagnose liver steatosis and cholestasis. This also holds true for possible adverse effects associated with the haematological system. The identification of the kidneys as the third most commonly affected organs was based on various histopathological changes for which no oral repeated dose toxicity studies for the 42 haematology-affecting cosmetic ingredients in safety evaluation reports issued between 2009 and 2019. *Red blood cells. **Mean corpuscular haemoglobin. *** Mean corpuscular volume. **** Mean corpuscular haemoglobin concentration

clear pattern could be identified. Therefore, characterisation of the toxic effects is limited to the observation that the most prominent alterations were the presence of hyaline droplets and cellular degeneration in the renal tubules. As previously mentioned, the studies used in the safety evaluation reports are not designed to investigate specific adverse effects, but rather indicate a general capability of a compound to induce harmful effects. Therefore, it is of utmost importance to interpret the findings presented here with caution to avoid incorrect conclusions. Nevertheless, two cosmetic ingredients, i.e., 2,7-naphthalenediol and Basic red 51, were demonstrated to affect three or more parameters associated with cholestasis, therefore possibly indicating a cholestasisinducing potential (SCCS 2010a, 2011). Moreover, HC red 7 , and sodium perborate and perboric acid provoked changes indicative of indirect haematotoxic effects. Indeed, in the safety evaluation of $\mathrm{HC}$ red 7 , additional effects are mentioned that could be of interest for further investigations (SCCS 2009). However, the studies in the safety evaluation of sodium perborate and perboric acid are old and poorly described; therefore, no conclusions can be drawn in this regard (SCCS 2010b). Overall, the outcome of the present study is in line with a screening of SCCS opinions published between 2000 and 2009 (Vinken et al. 2012). In fact, both 2,7-naphthalenediol and Basic red 51 were previously identified as plausible cholestasis-inducing compounds, meaning that they have been evaluated multiple times (Vinken et al. 2012). In this respect, repeated evaluations of a compound are a common event, as 74 of the total number of compounds (101) included in the current screening have been addressed by the SCCS, or its predecessors, more than once. There are various reasons for the re-evaluation of a cosmetic ingredient, for instance due to inadequate provision of data for 
Table 4 Identification of cosmetic ingredients provoking a change in parameters commonly used for the diagnosis of anaemia based on alterations observed in oral repeated dose toxicity studies described for the 42 haematology-affecting cosmetic ingredients in safety evaluation reports issued between 2009 and 2019

\begin{tabular}{|c|c|c|c|c|c|}
\hline Cosmetic ingredient & Function & $\begin{array}{l}\downarrow \text { Haematocrit/RBC/ } \\
\text { mean haemoglobin* }\end{array}$ & $\uparrow \mathrm{MCV}^{*} *$ & $\downarrow \mathrm{MCHC}^{* * *}$ & $\uparrow$ Reticulocytes \\
\hline 1-Hexyl 4,5-diamino pyrazole sulphate & $\begin{array}{l}\text { Hair dyeing ingredient used as an oxi- } \\
\text { dative hair colouring agent (precur- } \\
\text { sor). The oxidative colouring agent } \\
\text { and the developer are mixed at a ratio } \\
\text { of } 1+1 \text { to } 1+3\end{array}$ & $\mathrm{x}$ & $\mathrm{x}$ & & $\mathrm{x}$ \\
\hline $\begin{array}{l}\text { 1-Hydroxyethyl-4,5-diamino pyrazole } \\
\text { sulphate }\end{array}$ & $\begin{array}{l}\text { Hair dyeing ingredient used in oxida- } \\
\text { tive hair dye formulations after mix- } \\
\text { ing with peroxide }\end{array}$ & & $\mathrm{x}$ & & \\
\hline 2,6-Diaminopyridine & $\begin{array}{l}\text { Hair dyeing ingredient used in oxida- } \\
\text { tive hair colouring products after } \\
\text { mixing in a } 1: 1 \text { ratio with hydrogen } \\
\text { peroxide just prior to use }\end{array}$ & $\mathrm{x}$ & $\mathrm{x}$ & & $\mathrm{x}$ \\
\hline 2,7-Naphthalenediol & $\begin{array}{l}\text { Hair dyeing ingredient used in oxida- } \\
\text { tive and non-oxidative hair dye } \\
\text { formulations }\end{array}$ & $\mathrm{x}$ & & & \\
\hline $\begin{array}{l}\text { 2-Amino-4-hydroxyethylaminoanisole } \\
\text { sulphate }\end{array}$ & $\begin{array}{l}\text { Hair dyeing ingredient used in oxida- } \\
\text { tive hair dye formulations after } \\
\text { mixing the developer containing } \\
\text { oxidative agent }\end{array}$ & $\mathrm{x}$ & & & $\mathrm{x}$ \\
\hline 4-Chlorooresorcinol & $\begin{array}{l}\text { Hair dyeing ingredient used as a cou- } \\
\text { pler in oxidative hair dye formula- } \\
\text { tions }\end{array}$ & $\mathrm{x}$ & & & $\mathrm{x}$ \\
\hline 4-Nitrophenyl aminoethylurea & $\begin{array}{l}\text { Hair dyeing ingredient used as direct } \\
\text { dye in semi-permanent hair formula- } \\
\text { tions and as a hair colouring agent } \\
\text { (direct dye) in oxidative hair dye } \\
\text { formulations }\end{array}$ & $\mathrm{x}$ & & & $\mathrm{x}$ \\
\hline 5-Amino-6-chloro-o-cresol & $\begin{array}{l}\text { Hair dyeing ingredient used as a pre- } \\
\text { cursor for hair dyeing products }\end{array}$ & $\mathrm{x}$ & $\mathrm{x}$ & $\mathrm{x}$ & \\
\hline Acid black 1 & $\begin{array}{l}\text { Hair dyeing ingredient used as a direct } \\
\text { hair colouring agent in non-oxidative } \\
\text { hair dye formulations }\end{array}$ & $\mathrm{x}$ & & & $\mathrm{x}$ \\
\hline Acid orange 7 & $\begin{array}{l}\text { Hair dyeing ingredient used as a direct } \\
\text { hair colouring agent in non-oxidative } \\
\text { as well as in oxidative hair dye } \\
\text { formulations }\end{array}$ & & & & $\mathrm{x}$ \\
\hline Basic red 76 & $\begin{array}{l}\text { Hair dyeing ingredient used as a direct } \\
\text { dye for hair colouring products }\end{array}$ & $\mathrm{x}$ & & & $\mathrm{x}$ \\
\hline Basic violet 2 & $\begin{array}{l}\text { Hair dyeing ingredient used as a non- } \\
\text { reactive hair colouring agent in non- } \\
\text { oxidative hair dye-formulation and in } \\
\text { oxidative hair dye formulations. Also } \\
\text { used as a colourant in cosmetic prod- } \\
\text { ucts intended to come into contact } \\
\text { only briefly with the skin }\end{array}$ & $\mathrm{x}$ & $\mathrm{x}$ & & \\
\hline Basic yellow 57 & $\begin{array}{l}\text { Hair dyeing ingredient used as a direct } \\
\text { dye for hair colouring products }\end{array}$ & $\mathrm{x}$ & & & $\mathrm{x}$ \\
\hline CI 45,430 , erythrosine & $\begin{array}{l}\text { Used as a red colour additive in } \\
\text { cosmetics }\end{array}$ & $\mathrm{x}$ & & & \\
\hline $\begin{array}{l}\text { Disperse violet } 1 \text { (1,4-diamino-anth- } \\
\text { raquinone) }\end{array}$ & $\begin{array}{l}\text { Hair dyeing ingredient used as a hair } \\
\text { colour in semi-permanent hair dye } \\
\text { formulations }\end{array}$ & $\mathrm{x}$ & & & \\
\hline
\end{tabular}


Table 4 (continued)

\begin{tabular}{|c|c|c|c|c|c|}
\hline Cosmetic ingredient & Function & $\begin{array}{l}\downarrow \text { Haematocrit/RBC/ } \\
\text { mean haemoglobin* }\end{array}$ & $\uparrow \mathrm{MCV}^{* *}$ & $\downarrow \mathrm{MCHC}^{* * *}$ & $\uparrow$ Reticulocytes \\
\hline $\mathrm{HC}$ red 13 & $\begin{array}{l}\text { Hair dyeing ingredient used as a non- } \\
\text { reactive hair colouring agent ("direct } \\
\text { dye") in semi-permanent hair dye } \\
\text { formulations and oxidation hair dye } \\
\text { formulations }\end{array}$ & $\mathrm{x}$ & & $\mathrm{x}$ & \\
\hline $\mathrm{HC}$ red 7 & $\begin{array}{l}\text { Hair dyeing ingredient used in semi- } \\
\text { permanent hair dye formulations }\end{array}$ & $\mathrm{x}$ & & & \\
\hline HC yellow 2 & $\begin{array}{l}\text { Hair dyeing ingredient used in non- } \\
\text { oxidative hair dye-formulation and } \\
\text { oxidative formulations }\end{array}$ & $\mathrm{x}$ & $\mathrm{x}$ & $\mathrm{x}$ & \\
\hline HC yellow 7 & $\begin{array}{l}\text { Hair dyeing ingredient used in semi- } \\
\text { permanent hair dye formulations }\end{array}$ & $\mathrm{x}$ & & $\mathrm{x}$ & \\
\hline $\begin{array}{l}\text { Hydroxyethyl-3,4-methylenedioxyani- } \\
\text { line } \mathrm{HCl}\end{array}$ & $\begin{array}{l}\text { Hair dyeing ingredient used in oxida- } \\
\text { tive hair dye formulations after } \\
\text { mixing with the developer containing } \\
\text { hydrogen peroxide }\end{array}$ & $\mathrm{x}$ & & & $\mathrm{x}$ \\
\hline $\begin{array}{l}\text { Methoxypropylamino cyclohex- } \\
\text { enylidene ethoxyethylcyanoacetate } \\
\text { (S87) }\end{array}$ & $\begin{array}{l}\text { Used as a UV filter in personal care } \\
\text { products, including sun care cos- } \\
\text { metic formulations at a maximum } \\
\text { concentration of } 3 \% \mathrm{w} / \mathrm{w}\end{array}$ & $\mathrm{x}$ & & $\mathrm{x}$ & $\mathrm{x}$ \\
\hline Picramic acid and sodium picramate & $\begin{array}{l}\text { Hair dyeing ingredient used as a direct } \\
\text { hair colouring agent in non-oxidative } \\
\text { as well as in oxidative hair dye } \\
\text { formulations }\end{array}$ & $\mathrm{x}$ & $\mathrm{x}$ & $\mathrm{x}$ & $\mathrm{x}$ \\
\hline Sodium perborate and perboric acid & $\begin{array}{l}\text { Hair dyeing ingredient used in oxida- } \\
\text { tive hair colouring products after } \\
\text { mixing with water just prior to use }\end{array}$ & $\mathrm{x}$ & & & \\
\hline
\end{tabular}

*Red blood cell count

**Mean corpuscular volume

***Mean corpuscular haemoglobin concentration

safety evaluation in the first submission or due to a request from the industry for an extension of the allowed use concentration of the specific ingredient.

Since 2013, the animal testing ban has largely impeded the marketing of new cosmetic ingredients. This innovation issue will remain until there are suitable non-animal methods that address the most complex human toxicological endpoints that historically have been evaluated with animal RDT testing. Due to the complex interactions in a whole organism, it is very unlikely to find a one-to-one conversion from one in vivo to one in vitro test as replacement of RDT testing. Instead, it is envisaged that humanbased in silico, in vitro, and in chemico approaches, collectively known as new approach methodologies (NAMs), will comprise the next generation risk assessment (NGRA). Although scientific challenges remain to be tackled before NAMs are used by default in safety evaluations and advantages with their use, such as an increased relevance to human health, becomes evident. Indeed, NAMs have shown great promise to provide a large amount of data to fill information gaps in both hazard and exposure assessments (Rogiers et al. 2020). NGRA is anticipated to be hypothesis-driven and exposure-led, including multiple NAMs which are integrated and combined in novel approaches (Dent et al. 2018). Methods such as exposurebased waiving using thresholds of toxicological concern (TTC) for structurally related compounds and chemicals belonging to a defined chemical space may be satisfactory in case of very limited exposures (Kroes et al. 2007). Grouping of chemicals for read-across purposes can be performed at different levels of biological activity (e.g., common target organ, common critical effect, or mode of action) (Bal-Price and Meek 2017). Information about the effects of cosmetic ingredients on target organs will facilitate the development of NAMs, as they should be challenged with cosmetic ingredients as a proof-of-concept exercise, thereby making information on expected target organs and critical effect(s) essential. Hence, the results of this study call for prioritising the development of NAMs suitable to address biological activity and toxicity provoked by cosmetic ingredients in the liver and the haematological system. 
Acknowledgements The authors express gratitude to Mrs. Tineke Vanhalewyn for excellent assistance and to Mrs. Marleen Pauwels for kind guidance. This work was financially supported by Cosmetics Europe as part of the Long Range Science Strategy programme and by the European Chemical Industry Council (CEFIC).

Funding This work was financially supported by Cosmetics Europe as part of the Long Range Science Strategy programme and by the European Chemical Industry Council (CEFIC).

Data availability The datasets generated during and/or analysed during the current study are available from the corresponding author on reasonable request.

Code availability Microsoft ${ }^{\circledR}$ Office Excel version 16.10 (180210).

\section{Compliance with ethical standards}

Conflict of interest The authors declare that they have no conflict of interest.

Ethics approval Not applicable.

Consent to participate Not applicable.

Consent for publication Not applicable.

Open Access This article is licensed under a Creative Commons Attribution 4.0 International License, which permits use, sharing, adaptation, distribution and reproduction in any medium or format, as long as you give appropriate credit to the original author(s) and the source, provide a link to the Creative Commons licence, and indicate if changes were made. The images or other third party material in this article are included in the article's Creative Commons licence, unless indicated otherwise in a credit line to the material. If material is not included in the article's Creative Commons licence and your intended use is not permitted by statutory regulation or exceeds the permitted use, you will need to obtain permission directly from the copyright holder. To view a copy of this licence, visit http://creativecommons.org/licenses/by/4.0/.

\section{References}

Al-Eryani L, Wahlang B, Falkner KC et al (2015) Identification of environmental chemicals associated with the development of toxicant-associated fatty liver disease in rodents. Toxicol Pathol 43(4):482-497

Bal-Price A, Meek MEB (2017) Adverse outcome pathways: application to enhance mechanistic understanding of neurotoxicity. Pharmacol Ther 179:84-95

Barnett LMA, Cummings BS (2019) Cellular and molecular mechanisms of kidney toxicity. Semin Nephrol 39(2):141-151

Boone L, Meyer D, Cusick P et al (2005) Selection and interpretation of clinical pathology indicators of hepatic injury in preclinical studies. Vet Clin Pathol 34(3):182-188

Broadway-Duren JB, Klaassen H (2013) Anemias. Crit Care Nurs Clin N Am 25(4):411-426

Cascio MJ, DeLoughery TG (2017) Anemia: evaluation and diagnostic tests. Med Clin N Am 101(2):263-284

Cattley RC, Cullen JM (2013) Chapter 45-liver and gall bladder. In: Haschek CGR, Wallig MA (eds) Haschek and Rousseaux's handbook of toxicologic pathology, 3rd edn. Academic Press, Cambridge, pp 1509-1566

Daneshian M, Kamp H, Hengstler J et al (2016) Highlight report: launch of a large integrated European in vitro toxicology project: EU-ToxRisk. Arch Toxicol 90(5):1021-1024

David S, Hamilton JP (2010) Drug-induced liver injury. US Gastroenterol Hepatol Rev 6:73-80

Dent M, Teixeira Amaral R, Amores Da Silva P et al (2018) Principles underpinning the use of new methodologies in the risk assessment of cosmetic ingredients. Comput Toxicol 7:20-26

Desprez B, Dent M, Keller D et al (2018) A strategy for systemic toxicity assessment based on non-animal approaches: the cosmetics europe long range science strategy programme. Toxicol Vitro 50:137-146

EU (1976) Council Directive 76/768/EEC of 27 July 1976 on the approximation of the laws of the member states relating to cosmetic products. OV J L 262:169-200

EU (2003) Directive 2003/15/EC of the European Parliament and of the Council of 27 February 2003 amending Council Directive 76/768/ EEC on the approximation of the laws of the Member States relating to cosmetic products. $66 \mathrm{OL}$

EU (2008) Commission decision 2008/721/EC of 5 September 2008 setting up an advisory structure of scientific committees and experts in the field of consumer safety, public health and the environment and repealing decision 2004/210/EC. Off J L 241:21-30

EU (2009) Regulation (EC) No 1223/2009 of the European Parliament and of the Council of 30 November 2009 on cosmetic products. Off J L. 342, 22.12.2009, p 59-209

Gocht T, Berggren E, Ahr HJ et al (2015) The SEURAT-1 approach towards animal free human safety assessment. Altex 32(1):9-24

Greim H, Snyder R (2008) Toxicology and risk assessment: a comprehensive introduction. Wiley, Chichester

Grimes CN, Fry MM (2015) Nonregenerative anemia: mechanisms of decreased or ineffective erythropoiesis. Vet Pathol 52(2):298-311

Hall AP, Elcombe CR, Foster JR et al (2012) Liver hypertrophy: a review of adaptive (adverse and non-adverse) changes-conclusions from the 3rd International ESTP Expert Workshop. Toxicol Pathol 40(7):971-994

Hayes AW, Kruger CL (2014) Hayes' principles and methods of toxicology, 6th edn. CRC Press, Boca Raton

Ipsen DH, Lykkesfeldt J, Tveden-Nyborg P (2018) Molecular mechanisms of hepatic lipid accumulation in non-alcoholic fatty liver disease. Cell Mol Life Sci 75(18):3313-3327

Kim CH (2010) Homeostatic and pathogenic extramedullary hematopoiesis. J Blood Med 1:13-19

Kroes R, Renwick AG, Feron V et al (2007) Application of the threshold of toxicological concern (TTC) to the safety evaluation of cosmetic ingredients. Food Chem Toxicol 45(12):2533-2562

Laroche C, Annys E, Bender H et al (2019) Finding synergies for the 3Rs-repeated dose toxicity testing: report from an EPAA Partners' Forum. Regul Toxicol Pharmacol 108:104470

Lee WM (2013) Drug-induced acute liver failure. Clin Liver Dis 17(4):575-586

Mebius RE, Kraal G (2005) Structure and function of the spleen. Nat Rev Immunol 5(8):606-616

Michael B, Yano B, Sellers RS et al (2007) Evaluation of organ weights for rodent and non-rodent toxicity studies: a review of regulatory guidelines and a survey of current practices. Toxicol Pathol 35(5):742-750

OECD (2018) Test No. 408: repeated dose 90-day oral toxicity study in rodents, OECD guidelines for the testing of chemicals, section 4 . OECD Publishing, Paris

Onakpoya IJ, Heneghan CJ, Aronson JK (2019) Post-marketing withdrawal of 462 medicinal products because of adverse drug 
reactions: a systematic review of the world literature. BMC Med 14:10 (published correction appears in BMC Med. 2019 Mar 2;17(1):56)

Robles-Diaz M, Garcia-Cortes M, Medina-Caliz I et al (2015) The value of serum aspartate aminotransferase and gamma-glutamyl transpetidase as biomarkers in hepatotoxicity. Liver Int 35(11):2474-2482

Rogiers V, Benfenati E, Bernauer U et al (2020) The way forward for assessing the human health safety of cosmetics in the EU-workshop proceedings. Toxicology 436:152421

SCCS (Scientific Committee on Consumer Safety) (2009) Opinion on HC Red n 7. 8 December 2009 SCCS/1229/09

SCCS (Scientific Committee on Consumer Safety) (2010a) Opinion on 2,7-Naphthalenediol. 21 September 2010 SCCS/1366/10

SCCS (Scientific Committee on Consumer Safety) (2010b) Opinion on sodium perborate and perboric acid. 22 June 2010 SCCS/1345/10

SCCS (Scientific Committee on Consumer Safety) (2011) Opinion on Basic Red 51. 22 March 2011 SCCS/1332/10
SCCS (Scientific Committee on Consumer Safety) (2018) The SCCS notes of guidance for the testing of cosmetic ingredients and their safety evaluation, 10th revision, SCCS/1602/18.

Vilas-Boas V, Gijbels E, Cooreman A et al (2019) Industrial, biocide, and cosmetic chemical inducers of cholestasis. Chem Res Toxicol 32(7):1327-1334

Vinken M, Pauwels M, Ates G et al (2012) Screening of repeated dose toxicity data present in SCC(NF)P/SCCS safety evaluations of cosmetic ingredients. Arch Toxicol 86(3):405-412

Vinken M (2020) 3Rs toxicity testing and disease modelling projects in the European Horizon 2020 research and innovation program. EXCLI J 19:775-784

Publisher's Note Springer Nature remains neutral with regard to jurisdictional claims in published maps and institutional affiliations. 